\title{
Characterization of galls, insect galls and associated fauna of Ecological Station of Jataí (Luiz Antônio, SP)
}

\author{
Victor Satoru Saito ${ }^{1,3}$ \& Maria Virginia Urso-Guimarães ${ }^{2}$ \\ ${ }^{1}$ Programa de Pó-graduação em Ecologia e Recursos Naturais, \\ Universidade Federal de São Carlos - UFSCar, CEP 13565-905, São Carlos, SP, Brasil. \\ http://www.ppgern.ufscar.br/ \\ ${ }^{2}$ Universidade Federal de São Carlos - UFSCar, CEP 18052-780, Sorocaba, SP, Brasil. http://www. \\ sorocaba.ufscar.br/ufscarl \\ ${ }^{3}$ Corresponding author: Victor Satoru Saito,e-mail: victor.saito@gmail.com
}

SAITO, V.S. \& URSO-GUIMARÃES, M.V. Characterization of galls, insect galls and associated fauna of Ecological Station of Jataí (Luiz Antônio, SP). Biota Neotrop. 12(3): http://www.biotaneotropica.org.br/v12n3/ en/abstract?article+bn02312032012

Abstract: This is the first study about galls, gall makers and associated fauna of the Ecological Station of Jataí.
Galls are plant structures formed by abnormal growth of cells, tissues or organs induced by several organisms, as
fungous, nematoids and insects. Five areas of the conservation unity, two in the phytophysionomy of cerrado in
regeneration and three in the cerradão area were studied, totalizing 69 morphotypes of galls on 41 host species from
24 families. This is the first record of Annonaceae as the richest family in morphotypes in Brazil; 34 gall makers and
associated fauna were identified, which 23 Diptera (67.4\%), eight Hymenoptera ( $23.5 \%)$, two Hemiptera (5.8\%)
and one Thysanoptera (2.9\%). Were described 41 new morphotypes of gall and made the first characterization
of gall on Maprounea guianensis Aubl., Acosmium subelegans (Mohlenbr.) Yakovlev., Strychnos bicolor
Progel, Eriotheca gracilipes K. Schum., Stryphnodendron obovatum Benth., Broyesum gaudichaudii Trécul,
Psychotria suterella Müll. Arg., Psychotria trichophora Müll. Arg. and Serjania erecta Radlk. Keywords: Annonaceae, Cecidomyiidae, Cerrado, galling species, geographic distribution, host plant, parasitoid.

SAITO, V.S. \& URSO-GUIMARÃES, M.V. Caracterização de galhas, insetos galhadores e fauna associada de Estação Ecológica de Jataí (Luiz Antônio, SP). Biota Neotrop. 12(3): http://www.biotaneotropica.org.br/ v12n3/pt/abstract?article+bn02312032012

Resumo: Este é o primeiro estudo sobre galhas, insetos galhadores e fauna associada da Estação Ecológica de Jataí. Galhas são estruturas vegetais formadas por um crescimento anormal de células, tecidos ou órgãos induzido por vários organismos, como fungos, nematóides e insetos. Cinco áreas da unidade de conservação, dois na fitofisionomia de cerrado em regeneração e três na área de cerradão foram estudadas, totalizando 69 morfotipos de galhas em 41 espécies de plantas hospedeiras de 24 famílias. Este é o primeiro registro de Annonaceae como a família mais rica em morfotipos no Brasil; 34 insetos galhadores e fauna associada foram identificados, sendo 23 Diptera (67,4\%), oito Hymenoptera (23,5\%), dois Hemiptera (5,8\%) e um Thysanoptera (2,9\%). Foram descritos 41 novos morfotipos de galhas e foi feita a primeira caracterização de galhas em Xylopia aromatica (Lam.) Mart., Connarus suberosus Planch., Maprounea guianensis Aubl., Acosmium subelegans (Mohlenbr.) Yakovlev., Strychnos bicolor Progel, Eriotheca gracilipes K. Schum., Stryphnodendron obovatum Benth., Broyesum gaudichaudii Trécul, Psychotria suterella Müll. Arg., Psychotria trichophora Müll. Arg. e Serjania erecta Radlk.

Palavras-chave: Annonaceae, Cecidomyiidae, Cerrado, espécies galhadoras, distribuição geográfica, planta hospedeira, parasitoide. 


\section{Introduction}

Galls are plant structures formed by abnormal growth of cells, tissues or organs in response to stimuli caused by other organisms (Carneiro et al. 2009, Rohfritsch \& Shorthouse 1982). This abnormal growth is due to increase in cell volume (hypertrophy) and/or cell number (hyperplasia). A rich insect fauna is associated with the galls and includes predators, parasitoids, tenants and successors, so galls represent a true micro habitat where several tri-trophic relations are established (Maia 2001). A recent study estimated the richness of insect galls in about 120,000 species (Espirito Santo \& Fernandes 2007), making knowledge of this group essential for ecological studies.

In Neotropic, six orders of insects are cited by having representatives galling species, Diptera, Lepidoptera, Hymenoptera, Coleoptera, Hemiptera and Thysanoptera (Maia et al. 2008). Among these, there is a wide prevalence of galls induced by Diptera, were recorded over a thousand morphotypes, mainly driven by species of family Cecidomyiidae (Maia et al. 2008), which represent the group of predominantly insect galls in all zoogeographical regions of world (Gagné 1994). Julião et al. (2005) discusses the use of such groups as bioindicators because they are easy objects of study, due to the bodies remain locatable for much of their life cycle and are abundant in their hosts, although they are still few studies on the characterization of this fauna (Lara \& Fernandes 1996), despite efforts to work on characterization of galls and gall makers in areas of restinga (Maia 2005), Cerrado, rupestrian fields, semidecidual forest in the states of São Paulo and Minas Gerais (Urso-Guimarães \& Scarelli-Santos 2006, Urso-Guimaraes et al. 2003, Lara \& Fernandes 1996).

The Cerrado is a very devastated domain, especially in São Paulo, where only $5.48 \%$ of the original Cerrado is still available. There are few studies about galls in this biome in Sao Paulo, with only one gall characterization in Pé-de-Gigante Reserve (Urso-Guimarães \& Scarelli-Santos, 2006). The Ecological Station of Jataí (ESJATAÍ) is the largest conservation area of Cerrado in São Paulo and yet few studies on biodiversity of invertebrate were made, as well in other Brazilian cerrado areas, and most groups and communities have not been studied (Peruquetti 2004).

\section{Material and methods}

\section{Study area}

The ES JATAÍ is located in the city of Luiz Antônio, São Paulo, between coordinates $21^{\circ} 30^{\prime}$ and $21^{\circ} 40^{\prime} \mathrm{S}$ and $47^{\circ} 40^{\prime}$ and $47^{\circ} 50^{\prime} \mathrm{W}$ (Figure 1), Unit of Water Resources Management ${ }^{\circ} 9$ - Mogi Guaçu in region of Médio Mogi Guaçu (Pires et al. 2000). The climate is Aw of Koppen, or Tropical of central Brazil (Pires et al. 2000, Toppa et al. 2006). Altitude varies from $515 \mathrm{~m}$ to $835 \mathrm{~m}$ in altitude relative to sea level and located in the Paraná Sedimentary Basin (Toppa et al. 2006). In relation to vegetation types, ES JATAÍ has about $60 \%$ of cerradão, $20 \%$ of cerrado regeneration, $12 \%$ of Semideciduous Forest, $3 \%$ of lowland vegetation, $1 \%$ of campo sujo, $2 \%$ of recovery areas and less than $1 \%$ of Cerrado sensu stricto (Toppa et al. 2006, Fundação... et al. in prep).

\section{Experimental procedures}

\subsection{Sampling}

Five areas were chosen to sampling, three areas of cerradão and two of cerrado regeneration. These areas should have different degrees of conservation, as evidenced by the presence or absence of exotic grasses, palms and bromeliads.
Samples were collected in areas including the border of roads of ES Jataí, because as already described by Price et al. (1998), the border represent an environment with increased solar radiation and desiccation, where there is increased the richness of galls.

The coordinates of starting points of sampling:

1 - 21 $1^{\circ} 36^{\prime} 19.44^{\prime \prime} \mathrm{S}$ and $47^{\circ} 47^{\prime} 28.86^{\prime \prime} \mathrm{W}$ (geographical)

2 - $21^{\circ} 36^{\prime} 14.10^{\prime \prime} \mathrm{S}$ and $47^{\circ} 46^{\prime} 34.44^{\prime \prime} \mathrm{W}$ (geographical)

$3-21^{\circ} 36^{\prime} 2.81^{\prime \prime} \mathrm{S}$ and $47^{\circ} 45^{\prime} 38.32^{\prime}$ ' W (geographical)

$4-21^{\circ} 35^{\prime} 33.27^{\prime}$ ' S and $47^{\circ} 45^{\prime} 40.86^{\prime \prime} \mathrm{W}$ (geographical)

$5-21^{\circ} 37^{\prime} 48.48^{\prime}$ ' S and $47^{\circ} 42^{\prime} 33.15^{\prime \prime} \mathrm{W}$ (geographical)

The samples were obtained using methods described by Fernandes et al. (1995), Fernandes \& Negreiros (2006), Julião et al. (2005), occurred on days 19, 20 and 21 April 2010 and consisted of three random routes of an hour for each area, totaling 15 hours of sampling. According to Fernandes et al. (1995), the sampling during a weather station is sufficient to evaluate the number of galls per habitat, because of the absence of statistical difference in the results obtained, which were conducted in two seasons, dry and rainy seasons. This is due to the galls are sessile and remain attached to host plants, which makes possible accounting of galls even after adult emergence.

The stems of plants with galls were collected and placed in individual plastic bags, tagged and taken to laboratory where were placed in plastic bottles covered with fine mesh to wait for the emergence of gall maker. Exsiccates were made from plants collected for later identification by specialists. The collection of sentinel plants is deposited in the Herbarium of the UFSCar campus Sorocaba.

\subsection{Criteria for characterization of the galls}

The morphology of gall is considered of great taxonomic value because of high specificity of galling species and host plant. Moreover, their characters are easier to observe than those of adults or immature stages of galling species, given the diminutive size of these (Maia 1995). By morphotype, understood to be the characters used as shape (Figure 2), color (Figure 3), pubescence (Figure 4), grouping (Figure 5) and organ of occurrence of gall on the host plant (Figure 6) (Maia 1995).

The characterization of galls was done using a synthesis of the nomenclatures presented in works in the area as Möhn (1961), Maia (2001), Urso-Guimarães et al. (2003), Urso-Guimarães \& Scarelli-Santos (2006) and review of the specificity of galls made by Carneiro et al. (2009). Galls that were not found galling species the identification where made by similarity to several studies (Urso-Guimarães \& Scarelli-Santos 2006, Maia \& Fernandes 2004, Gonçalves-Alvim \& Fernandes 2001, Maia et al. 2008, Carneiro et al. 2009, Urso-Guimarães et al. 2003).

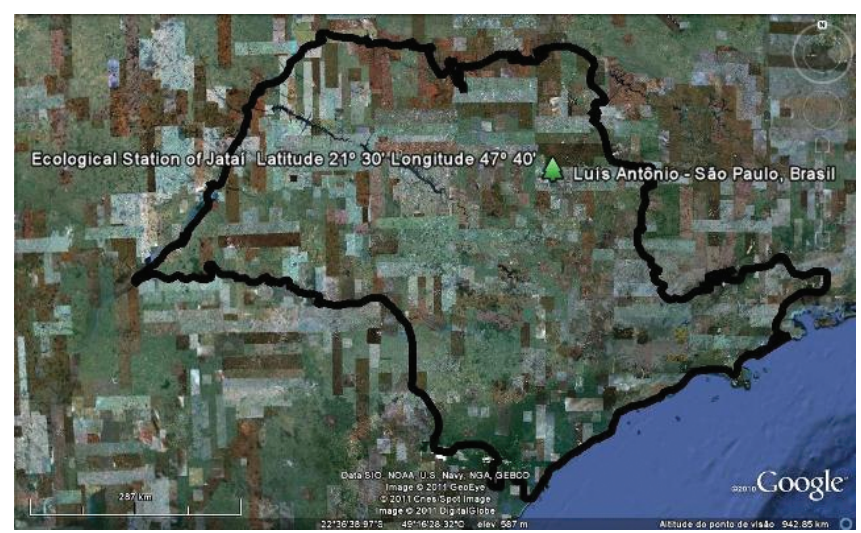

Figure 1. Location of Ecological Station of Jataí, SP (fonte: Google Earth Free). 
Were made permanent slides with cecidomyiids according to procedures of Gagné (1989). To identify the cecidomyiids was used identification key of Gagné (1994). The parasitoids were identified to family using identification keys of Kristensen (1991). Specimens of insect galls and their associated fauna sampled are deposited in the Didactic and Scientific Collection of Invertebrates of UFSCar Campus Sorocaba.

\section{Results}

Were found 69 morphotypes of galls in 41 plant species from 24 families (Table 1). Of all the insects identified, 23 are Diptera (67.6\%), eight are Hymenoptera (23.5\%), two are Hemiptera (5.9\%) and one Thysanoptera (2.9\%) (Figure 7 ). If we consider only the galling habit $(\mathrm{n}=25)$, the percentage of Cecidomyiidae (single

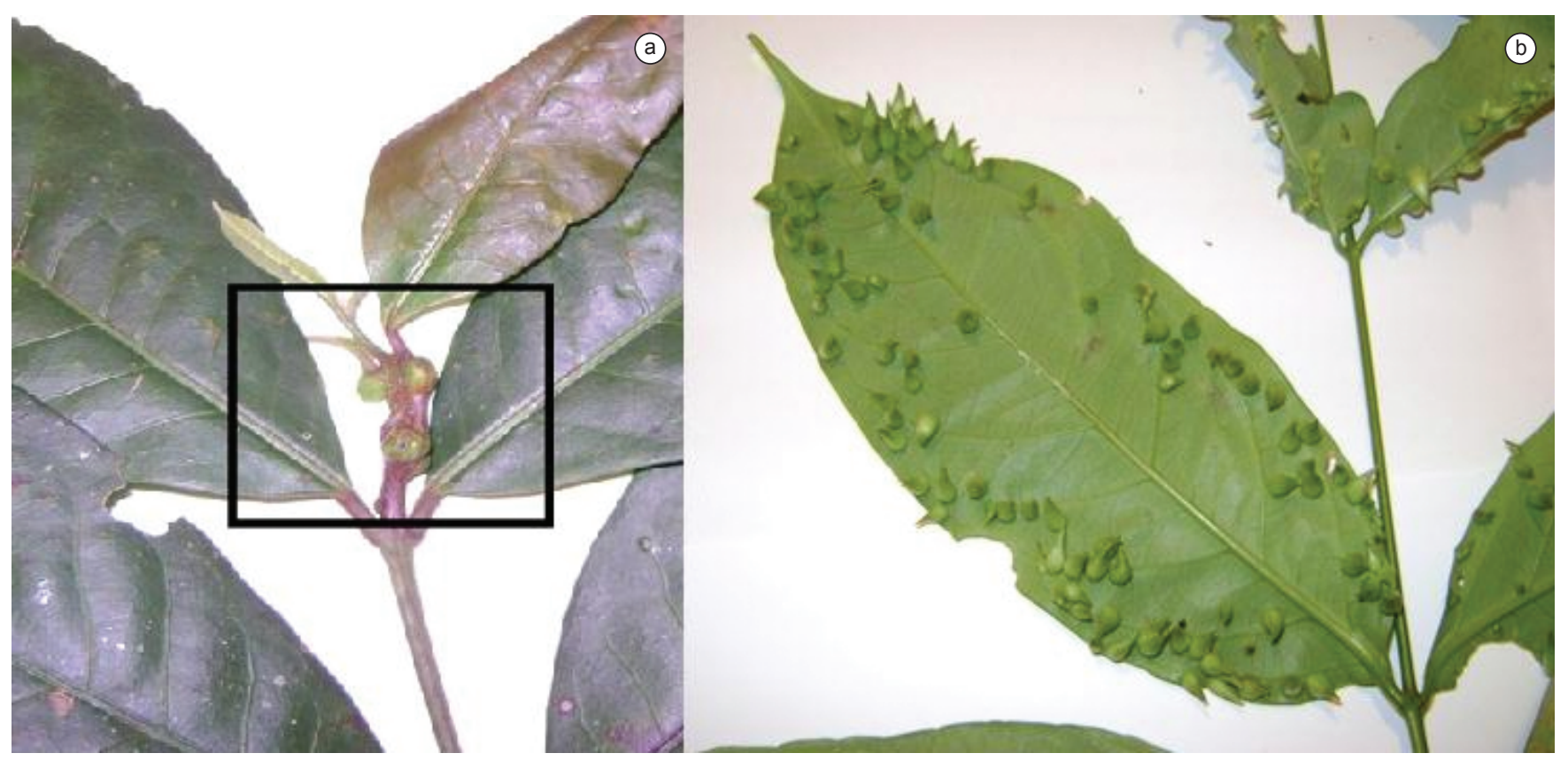

Figure 2. Example of shapes of galls characterized in the Ecological Station of Jataí (SP). a) globoid form (Siparuna guianensis Aubl), b) conic form (Banisteriopsis pubipetala (A. Juss.) Cuatrec.).
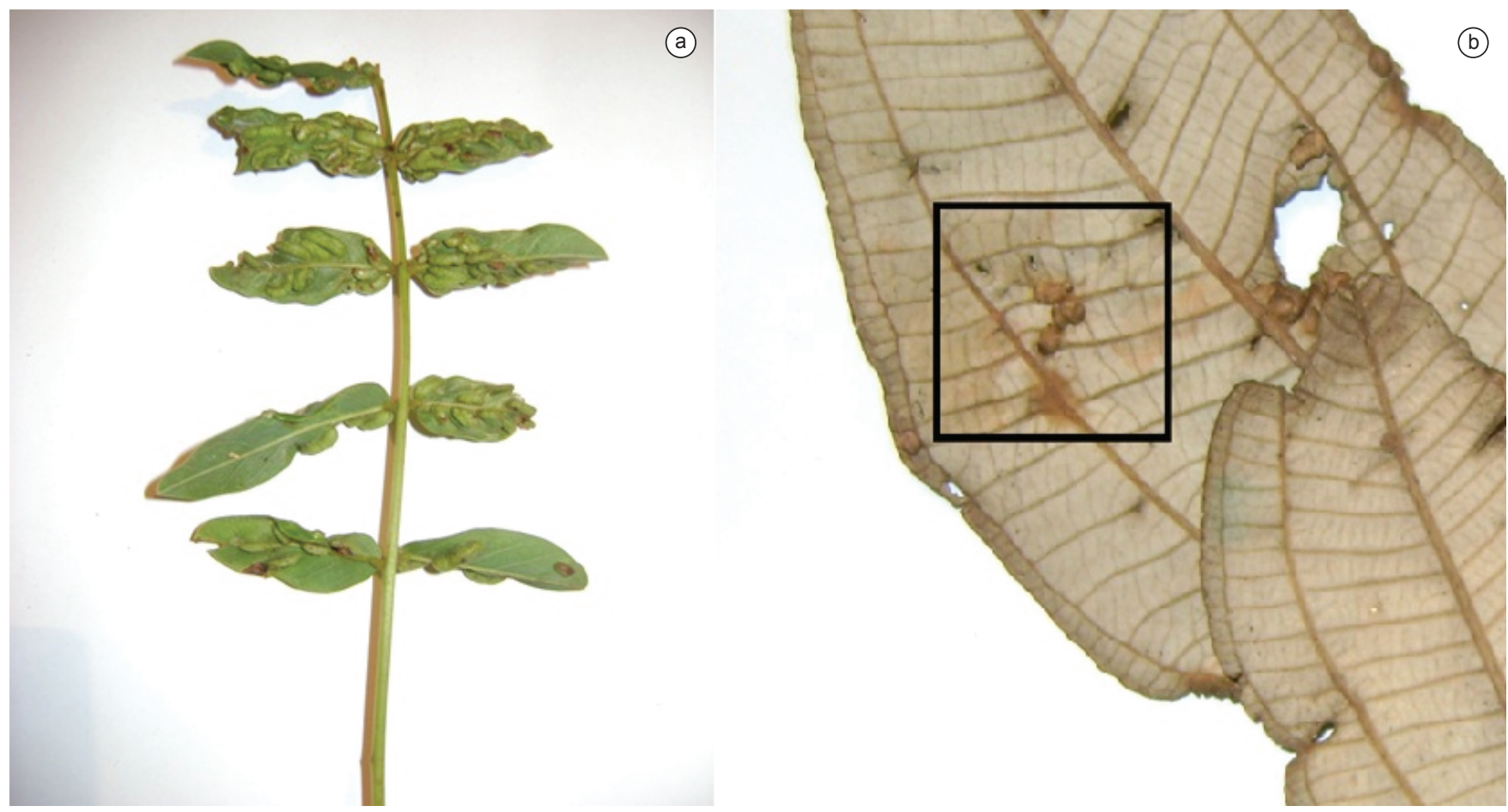

Figure 3. Example of the coloration of galls characterized in the Ecological Station of Jataí (SP). a) green (Andira sp.), b) cream (Miconia albicans Sw.). 
Saito, V.S. \& Urso-Guimarães, M.V.

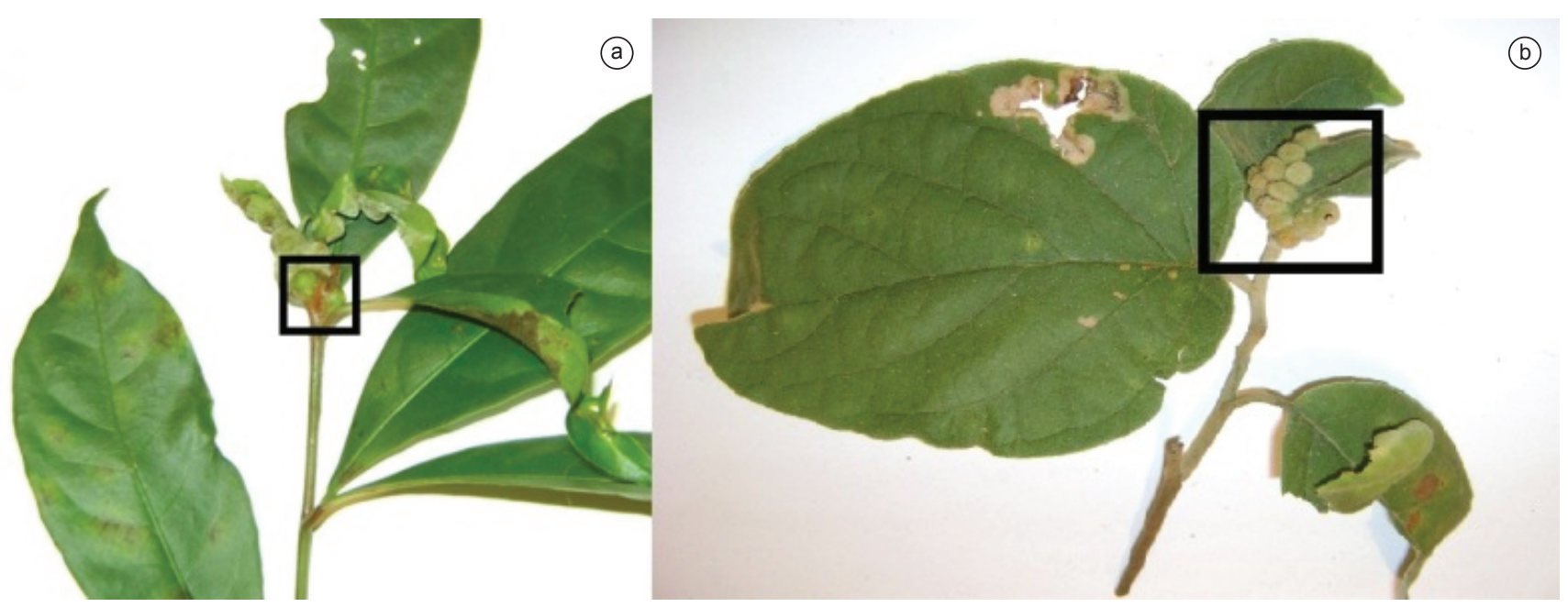

Figure 4. Example of the presence and absence of pubescence in the galls characterized in the Ecological Station of Jataí (SP). a) glabrous (without trichomes) (Nectandra sp.), b) pubescent (with trichomes) (Bauhinia rufa Graham).

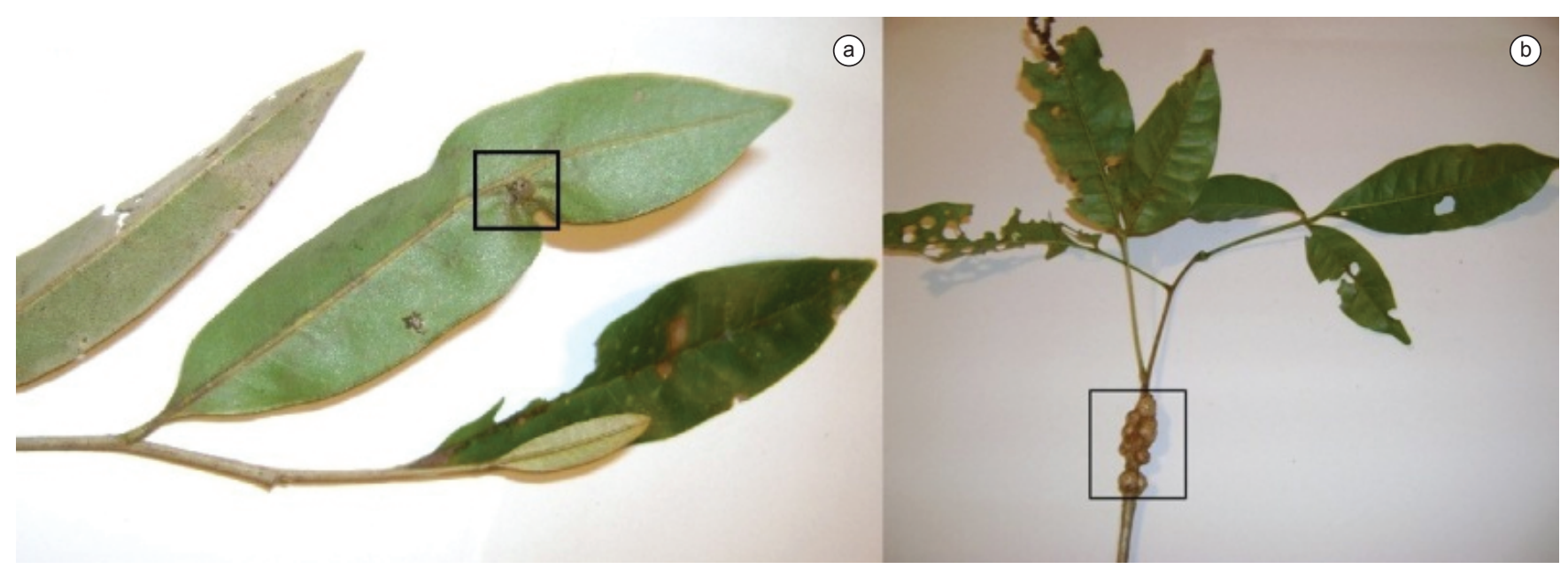

Figure 5. Example of isolated (a) (Duguetia furfuracea (A. St.-Hil.) Saff.) and grouped (b) (Arrabidaea sp.) galls characterized in the Ecological Station of Jataí (SP).

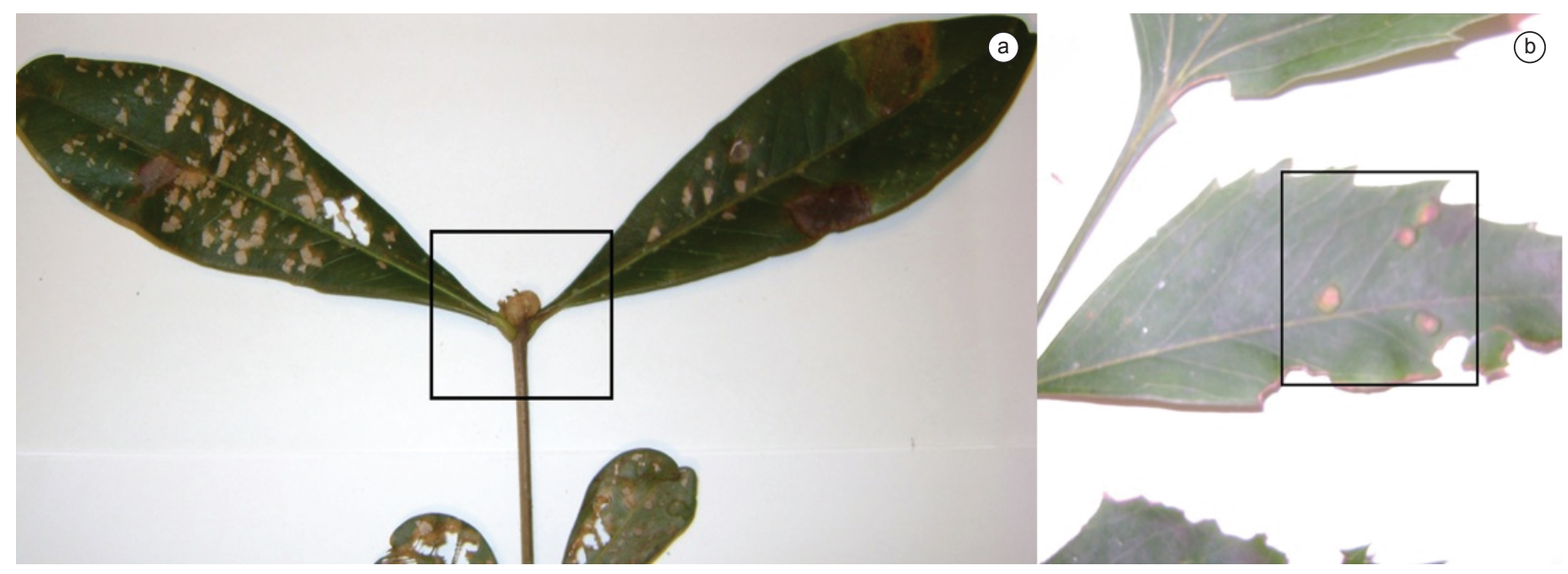

Figure 6. Example of occurence organs of galls characterized in the Ecological Station of Jataí (SP). a) apical gem (Byrsonima cf intermedia A. Juss.),b) leaf (Acosmium cf subelegans (Mohlenbr.) Yakovlev.). 


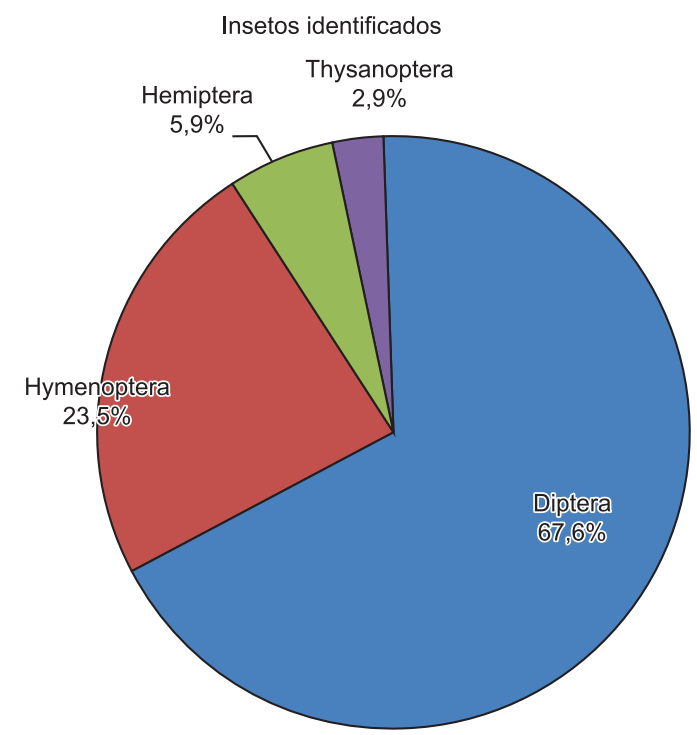

Figure 7. Percentage of the orders of insects found in galls of Ecological Station of Jataí, SP.

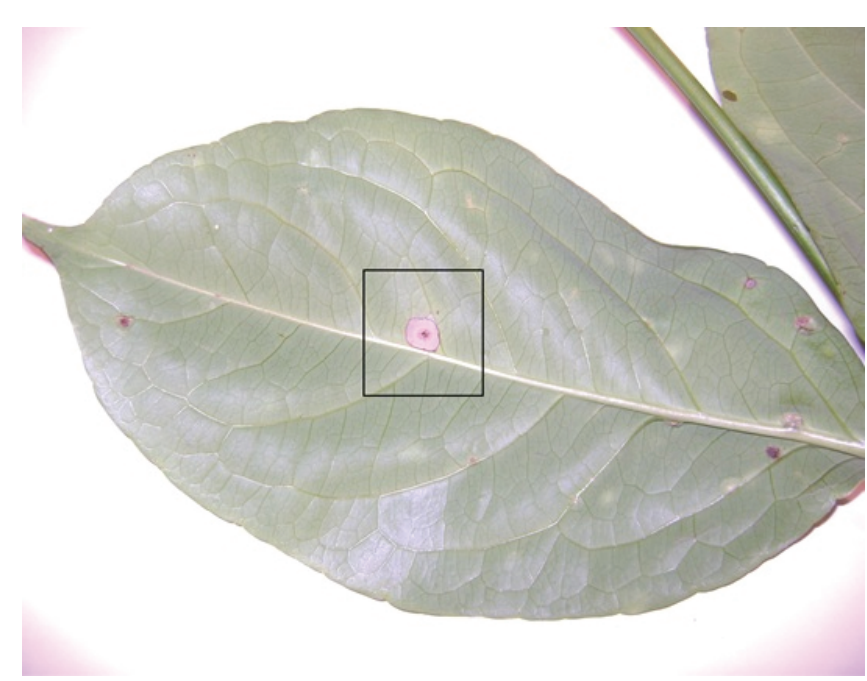

Figure 8. Example of gall characterized in the Ecological Station of Jataí (SP) with discoid form and may be a scar from another form.

Table 1. Table of characterization of the morphotypes of galls found in the Ecological Station of Jataí, SP, by species of host plant.

\begin{tabular}{|c|c|c|c|c|c|c|c|}
\hline Family & Specie & Organ & Shape & $\begin{array}{l}\text { Pubes } \\
\text { cence }\end{array}$ & Ocurrence & Color & $\begin{array}{l}n^{0} \text { of } \\
\text { type }\end{array}$ \\
\hline Anacardiaceae & Tapirira guianensisAubl. & leaf & point & no & isolated & Black & 1 \\
\hline \multirow[t]{10}{*}{ Annonaceae } & Annona coriacea Mart. & Leaf & discoid & no & isolated & Green and brown & 2 \\
\hline & Annona crassiflora Mart. & Leaf & discoid & no & isolated & Green and brown & 3 \\
\hline & \multirow[t]{5}{*}{ Duguetia furfuracea (A. St.-Hil.) Saff. } & Leaf & globular & no & isolated & Brown & 4 \\
\hline & & Leaf & discoid & no & isolated & Brown & 5 \\
\hline & & Leaf & winding & no & isolated & Green & 6 \\
\hline & & Leaf & swelling & no & isolated & Green & 7 \\
\hline & & Leaf & cylindrical & no & isolated & Green & 8 \\
\hline & \multirow[t]{3}{*}{ Xylopia aromatica (Lam.) Mart. } & Leaf & discoid & no & isolated & Brown & 9 \\
\hline & & Leaf & globular & no & grouped & Black & 10 \\
\hline & & Leaf & discoid & yes & isolated & Red & 11 \\
\hline Asteraceae & Gochnatia pulchra Cabrera & Leaf & globular & yes & isolated & Cream & 12 \\
\hline \multirow[t]{4}{*}{ Bignoniaceae } & \multirow{4}{*}{ Arrabidaea sp. } & Leaf bud & globular & yes & grouped & Brown & 13 \\
\hline & & Leaf & globular & yes & grouped & Brown & 14 \\
\hline & & Stem & swelling & no & isolated & Brown & 15 \\
\hline & & Leaf & discoid & no & isolated & Green and brown & 16 \\
\hline \multirow[t]{2}{*}{ Chrysobalanaceae } & \multirow[t]{2}{*}{ Couepia grandiflora Mart. \&Zucc. } & Leaf & globular & no & isolated & Green & 17 \\
\hline & & Leaf & swelling & no & isolated & Red & 18 \\
\hline Connaraceae & Connarus suberosus Planch. & Leaf & discoid & no & isolated & Brown & 19 \\
\hline \multirow{2}{*}{ Erythroxylaceae } & \multirow{2}{*}{ Erythroxylum suberosum A. St. -Hill. } & Stem & swelling & no & isolated & Brown & 20 \\
\hline & & Leaf & discoid & no & isolated & Brown & 21 \\
\hline \multirow[t]{4}{*}{ Euphorbiaceae } & Mabea fistulifera Mart. & Leaf & discoid & no & isolated & Green & 22 \\
\hline & Manihot caerulescens Pohl & Leaf & cylindrical & no & isolated & Brown & 23 \\
\hline & \multirow[t]{2}{*}{ Maprounea guianensis Aubl. } & Stem & swelling & no & isolated & Brown & 24 \\
\hline & & Leaf & winding & no & isolated & Green & 25 \\
\hline \multirow[t]{6}{*}{ Fabaceae } & $\begin{array}{l}\text { Acosmium cf subelegans (Mohlenbr.) } \\
\text { Yakovlev. }\end{array}$ & Leaf & discoid & no & isolated & Red & 26 \\
\hline & Andira sp. & Leaf & ravioli & no & isolated & Green & 27 \\
\hline & Bauhinia rufa Graham & Leaf & globular & yes & isolated & Brown & 28 \\
\hline & \multirow[t]{2}{*}{ Hymenaea sp. } & Leaf & discoid & no & isolated & Brown & 29 \\
\hline & & Leaf & globular & no & isolated & Green & 30 \\
\hline & Senna sp. & Leaf & discoid & yes & isolated & Brown & 31 \\
\hline Lauraceae & Nectandra sp. & Leaf & globular & no & isolated & Brown & 32 \\
\hline
\end{tabular}


Table 1. Continued...

\begin{tabular}{|c|c|c|c|c|c|c|c|}
\hline Family & Specie & Organ & Shape & $\begin{array}{l}\text { Pubes } \\
\text { cence }\end{array}$ & Ocurrence & Color & $\begin{array}{l}n^{0} \text { of } \\
\text { type }\end{array}$ \\
\hline & Ocotea corymbosa (Meisn.) Mez & Leaf & point & no & isolated & Green & 33 \\
\hline Loganiaceae & Strychnos bicolor Progel & Stem & swelling & no & isolated & Brown & 34 \\
\hline \multirow[t]{9}{*}{ Malpighiaceae } & Byrsonima cf intermedia A. Juss. & Leaf bud & swelling & no & isolated & Brown & 35 \\
\hline & & Leaf & triangular & no & isolated & Green-brown & 36 \\
\hline & & Stem & swelling & no & isolated & Brown & 37 \\
\hline & & $\begin{array}{l}\text { Apical } \\
\text { bud }\end{array}$ & globular & no & grouped & Brown & 38 \\
\hline & & Stem & globular & no & grouped & Brown & 39 \\
\hline & & Leaf & discoid & no & isolated & Brown & 40 \\
\hline & $\begin{array}{l}\text { Banisteriopsis pubipetala (A. Juss.) } \\
\text { Cuatrec. }\end{array}$ & Leaf & conical & no & isolated & Green & 41 \\
\hline & & Leaf & discoid & no & isolated & Brown & 42 \\
\hline & & Leaf & triangular & no & isolated & Green & 43 \\
\hline Malvaceae & Eriotheca gracilipes K. Schum. & Leaf & discoid & yes & isolated & Red & 44 \\
\hline Melastomataceae & Miconia albicans Sw. & Leaf & globular & no & grouped & Brown & 45 \\
\hline Minasaceae & Stryphnodendron obovatum Benth. & Leaf & discoid & no & isolated & Green and brown & 46 \\
\hline Moraceae & Broyesum gaudichaudii Trécul & Leaf & discoid & no & isolated & Brown & 47 \\
\hline \multirow[t]{7}{*}{ Myrtaceae } & Eugenia aurata $\mathrm{O}$. Berg & Stem & swelling & no & isolated & Brown & 48 \\
\hline & & Leaf & discoid & no & isolated & Brown & 49 \\
\hline & Eugenia bimarginata $D C$. & Leaf & discoid & no & isolated & Brown & 50 \\
\hline & Eugenia punicifolia Kunth (DC.) & Leaf & triangular & no & isolated & Green and brown & 51 \\
\hline & & Leaf bud & swelling & no & isolated & Green & 52 \\
\hline & Myrcia cf lingua $\mathrm{O}$. Berg (Mattos) & Leaf & discoid & no & isolated & Brown & 53 \\
\hline & sp. 1 & Leaf & discoid & no & isolated & Green & 54 \\
\hline Ochnaceae & Ouratea spectabilis Mart. exEngl. & Leaf & discoid & no & isolated & Brown & 55 \\
\hline \multirow[t]{2}{*}{ Proteaceae } & Roupala montana Aubl. & Leaf & discoid & no & isolated & Green & 56 \\
\hline & & Stem & globular & no & isolated & Brown & 57 \\
\hline \multirow[t]{4}{*}{ Rubiaceae } & Psychotria carthagenensis Jacq. & Leaf & globular & no & isolated & Brown & 58 \\
\hline & Psychotria cf suterella Müll.Arg. & Leaf & swelling & no & isolated & Green & 59 \\
\hline & & Stem & swelling & no & isolated & Green & 60 \\
\hline & Psychotria cf trichophora Müll.Arg. & Leaf & discoid & yes & isolated & Brown & 61 \\
\hline \multirow[t]{2}{*}{ Sapindaceae } & Serjania cf erecta Radlk. & Leaf & discoid & no & isolated & Green-brown & 62 \\
\hline & & Stem & swelling & no & isolated & Brown & 63 \\
\hline \multirow[t]{2}{*}{ Sapotaceae } & Pouteria torta (Mart.) Radlk. & Leaf & cylindrical & yes & isolated & Green & 64 \\
\hline & & Stem & swelling & no & isolated & Brown & 65 \\
\hline \multirow[t]{3}{*}{ Siparunaceae } & Siparuna guianensis Aubl. & Leaf & swelling & no & isolated & Green & 66 \\
\hline & & Stem & globular & no & grouped & Green & 67 \\
\hline & & Leaf & globular & yes & isolated & Brown & 68 \\
\hline Vochysiaceae & Qualea grandiflora Mart. & Stem & swelling & no & isolated & Brown & 69 \\
\hline
\end{tabular}

family found for Diptera) is even greater, with $88 \%$. In addition, all Hymenoptera found in the galls are parasitoids of the families Eurytomidae, Torymidae and Eulophidae (Table 2). Of the 41 host plants, in 20 of them were identified insects with galling habit, tenant or parasitoid. Were identified 34 insects in galls, 25 were galling habit, one tenant and eight parasitoids. Only nine insects were obtained and identified from the rearing and emergence of the gall, the other 25 were determined based on the similarity to the description of the gall in several studies (Table 1).

The galls characterized for Maprounea guianensis Aubl. (Euphorbiaceae), Acosmium subelegans (Mohlenbr.) Yakovlev. (Fabaceae), Strychnos bicolor Progel (Loganiaceae), Eriotheca gracilipes K. Schum. (Malvaceae), Stryphnodendron obovatum Benth. (Minasaceae), Broyesum gaudichaudii Trécul (Moraceae),
Psychotria suterella Müll. Arg., Psychotria trichophora Müll. Arg. (Rubiaceae) and Serjania erecta Radlk. (Sapindaceae) are the first records of gall in these species. According to the list of species of Management Plan of ES JATAÍ (2010), from 41 plant species found in this study, four of which do not appear on the list of species. The new species recorded are Psychotria carthagenensis Jacq., P. tricophora Müll. Arg., P. suterella Müll. Arg. (Rubiaceae) and Serjania erecta Radlk. (Sapindaceae).

For the organ were where found galls, $75 \%$ were on leaves, $19 \%$ on stems, $4,5 \%$ on leaf buds and $1.5 \%$ on the apical bud (Table 1 ). Regarding the shape of galls sampled, about $35 \%$ had discoid pattern, $23 \%$ swelling, $23 \%$ globular, $6 \%$ cylindrical, $4 \%$ triangular, $3 \%$ point, other patterns found were rolling around $3 \%, 1.5 \%$ ravioli and $1.5 \%$ conical (Table 1). Regarding the color of the galls, about $52.1 \%$ were 
Table 2. Table of the presented insects in the galls sampled in the Ecological Station of Jataí, SP, their habits and the identification method.

\begin{tabular}{|c|c|c|c|c|}
\hline Host plant & Insect & Habit & Reference & $\begin{array}{l}N^{0} \text { of } \\
\text { type }\end{array}$ \\
\hline \multirow[t]{4}{*}{ Duguetia furfuraceae } & $\begin{array}{l}\text { Bruggmanniella duguetiae Urso-Guimarães \& } \\
\text { Amorim, } 2005 \text { (Cecidomyiidae) }\end{array}$ & galling & Urso-Guimarães \& Scarelli-Santos (2006) & 6 \\
\hline & Hymenoptera & parasitoid & Urso-Guimarães \& Scarelli-Santos (2006) & 6 \\
\hline & Cecidomyiidae sp.1 & galling & Urso-Guimarães \& Scarelli-Santos (2006) & 10 \\
\hline & Eulophidae (Hymenoptera) & parasitoid & Obtained & 4 \\
\hline Annona crassiflora & Hemiptera & galling & Maia \& Fernandes (2004) & 7 \\
\hline Annona coriacea & Lasiopteridi sp.1 (Cecidomyiidae) & galling & Urso-Guimarães \& Scarelli-Santos (2006) & 8 \\
\hline Gochnatia pulchra & Cecidomyiidae sp. 2 & galling & Urso-Guimarães \& Scarelli-Santos (2006) & 12 \\
\hline \multirow[t]{2}{*}{ Arrabidaea sp. } & Cecidomyiidae sp. 3 & galling & Gonçalves-Alvim \& Fernandes (2001) & 13 \\
\hline & Cecidomyiidae sp.4 & galling & Gonçalves-Alvim \& Fernandes (2001) & 14 \\
\hline \multirow[t]{3}{*}{ Erythroxylum suberosum } & Cecidomyiidae sp.5 & galling & Maia \& Fernandes (2004) & 20 \\
\hline & Thysanoptera & galling & Obtained & 21 \\
\hline & Hymenoptera & parasitoid & Obtained & 21 \\
\hline Manihot caerulescens & $\begin{array}{l}\text { Iatrophobia brasiliensis Rübsaamen, } 1916 \\
\text { (Cecidomyiidae) }\end{array}$ & galling & Maia et al. (2008) & 22 \\
\hline Andira sp. & $\begin{array}{l}\text { Andirodiplosis bahiensis Tavares, } 1920 \\
\text { (Cecidomyiidae) }\end{array}$ & galling & Carneiro et al. (2009) & 26 \\
\hline Bauhinia rufa & Neolasioptera sp. 1 (Cecidomyiidae) & galling & Urso-Guimarães et al. (2003) & 30 \\
\hline Ocotea corymbosa & Coccicidae (Hemiptera) & galling & Maia et al. (2008) & 32 \\
\hline Nectandra sp. & Neolasioptera sp. 2 (Cecidomyiidae) & galling & Maia et al. (2008) & 33 \\
\hline \multirow[t]{2}{*}{ Byrsonima cf intermedia } & Cecidomyiidae sp. 6 & galling & Gonçalves-Alvim \& Fernandes (2001) & 35 \\
\hline & Cecidomyiidae sp.7 & galling & Gonçalves-Alvim \& Fernandes (2001) & 43 \\
\hline \multirow[t]{2}{*}{ Banisteriopsis pubipetala } & Clinodiplosis sp. (Cecidomyiidae) & galling & Urso-Guimarães \& Scarelli-Santos (2006) & 36 \\
\hline & Eurytomidae (Hymenoptera) & parasitoid & Obtained & 39 \\
\hline Miconia albicans & Cecidomyiidae sp. 8 & galling & Maia \& Fernandes (2004) & 45 \\
\hline Eugenia aurata & Cecidomyiidae sp.9 & galling & Obtained & 49 \\
\hline Eugenia aurata & Hymenoptera & parasitoid & Obtained & 49 \\
\hline Eugenia punicifolia & Cecidomyiidae sp. 10 & galling & Gonçalves-Alvim \& Fernandes (2001) & 52 \\
\hline Eugenia aurata & Lasiopteridi sp.2 (Cecidomyiidae) & galling & Maia et al. (2008) & 50 \\
\hline Eugenia bimarginata & Lasiopteridi/Asphondylia (Cecidomyiidae) & galling & $\begin{array}{l}\text { Maia et al. (2008) and Scarelli- } \\
\text { Santos et al. (2005) }\end{array}$ & 53 \\
\hline Roupala montana & Cecidomyiidae sp.11 & galling & Gonçalves-Alvim \& Fernandes (2001) & 56 \\
\hline Psychotria carthaginensis & Oligotrophini (Cecidomyiidae) & galling & Maia et al. (2008) & 58 \\
\hline \multirow[t]{4}{*}{ Pouteria torta } & Youngomyia pouteriae Maia, 2001(Cecidomyiidae) & galling & Urso-Guimarães \& Scarelli-Santos (2006) & 64 \\
\hline & Trotteria quadridentata Maia, 2001(Cecidomyiidae) & Tenant & Obtained & 64 \\
\hline & Eurytomidae (Hymenoptera) & parasitoid & Obtained & 64 \\
\hline & Torymidae (Hymenoptera) & parasitoid & Obtained & 64 \\
\hline Qualea grandiflora & Hymenoptera & parasitoid & Gonçalves-Alvim \& Fernandes (2001) & 69 \\
\hline
\end{tabular}

brown, $27.5 \%$ were green, $7 \%$ were green and brown (depending on the stage that was the gall), 5.6\% were red, 2, $8 \%$ were black, $2.8 \%$ were green-brown and cream were $1.4 \%$ (Table 1). Galls were found isolatly (74.2\%) or grouped (25.8\%) (Table 1). For pubescence, $85.5 \%$ were glabrous and $14.4 \%$ present trichomes (Table 1).

\section{Discussion}

This study reported the galling insects, the associated fauna and their host plants in cerrado vegetation in the state of São Paulo, an area with limited studies. In this work the first records of galls in nine plant species were made, which shows how galls, gall makers and associated insects were little studied in the cerrado lato sensu the state of São Paulo, with many areas yet to be characterized. For 69 morphotypes characterized were found similar descriptions of only 24 in literature. Considering the high specificity of the relationship gall- gall maker, revised by the recent work of Carneiro et al. (2009), which indicates that each gall is specific as to their host plant and that his gall is a unique interaction between them, this indicates possibly 45 morphotypes (65.2\%) who have never been described representing unknown species to science. This high percentage of unknown galls shows the lack of studies that characterize the galling community for cerrado of São Paulo, and which make the identification of gall maker with the use of the gall a more reliable methodology.

The sampling effort was 15 hours, a low figure compared to the monthly sampling for one year made by Bregonci et al. (2010), the monthly samplings for six months by Gonçalves-Alvim \& Fernandes (2001), the monthly samplings for over a year of Urso-Guimarães \& Scarelli-Santos (2006) and the 66 hours of samplings of Fernandes $\&$ Negreiros (2006). Of these works, only Fernandes \& Negreiros (2006) used the same methodology, yet despite the difference in 
sampling methodology, we can consider that all other studies had higher samplings effort that the present study. Despite the relatively low sampling effort, the richness of galls morphotypes found in this study was higher than three of them (Bregonci et al. 2010, UrsoGuimarães \& Scarelli-Santos 2006, Fernandes \& Negreiros 2006).

The richest family in diversity gall morphotypes was Annonaceae, followed by Malpighiaceae, Myrtaceae and Fabaceae. These data differs slightly from the expected. In literature, Fabaceae, Myrtaceae and Euphorbiaceae are cited as the richest families of galls (Gagné 1994), for example, Fabaceae was appointed as the richest in the cerrado by Gonçalves-Alvim \& Fernandes (2001) and UrsoGuimarães \& Scarelli-Santos (2006). It is therefore the first record of Annonaceae as the richest family in galls in a study area.

The richest host plant on types of galls was Byrsonima cfintermedia A. Juss. (Malpighiaceae) with six different morphotypes, followed by Duguetia furfuracea (A. St.-Hil.) Saff. (Annonaceae), with five. Urso-Guimarães \& Scarelli-Santos (2006) found Duguetia furfuracea (A. St.-Hil.) Saff. (Annonaceae) as the richest host plant in another cerrado area of São Paulo and this results indicates the importance of this host plant to the gall makers and associated fauna in this vegetation.

The fact that $75 \%$ of the galls have been found in leaves, corroborate the pattern found in studies in Brazil, that indicates the leaf as organ most commonly attacked by gall makers (Maia et al. 2008, Maia 2001, Urso-Guimarães et al. 2003, Fernandes \& Negreiros 2006) and with the world pattern found by Mani (1964). This pattern of occurrence in the leaves happens because the leaves are abundant resources and constant (Maia 2001), besides having a continuous flow of nutrients needed for the maintenance of photosynthesis (Whitham 1978). Another important factor is that females of Cecidomyiidae, most of the gall makers, has a very small size $(1-5 \mathrm{~mm})$, their ovipositor is fragile and can only lay eggs on tender tissues (Gagné 1994). The leaves are in constant renewal and derives most tender tissues of the host plants, which may also explain this preference.

The patterns for gall shape found in this study corroborate the patterns found in other studies, (Fernandes \& Negreiros 2006, Bregonci et al. 2010, Santos et al. 2011) with the predominance of discoid shape $(34.7 \%)$, followed by swellings and globular $(23.1 \%$ each). The fact that more discoid was found should be viewed with caution, because this shape may mean an early stage of a globular gall or even a scar of gall of another shape, as conical or globular (Figure 8).

Another point to note is the subjectivity present in the descriptions of the galls in the literature. Although several studies using the same characteristics (shape, pubescence, distribution, organ attacked and color), the descriptions are discrepant and the nomenclature used is not always the same. To standardize the descriptions in this study were examined pictures of the shapes of galls, in addition to the table.

As for pubescence, in $14.2 \%$ of galls with parasitoids, were observed trichomes, while the percentage of trichomes described for all galls is $14.4 \%$. These data reinforce Urso-Guimarães et al. (2003) whose found parasitic Hymenoptera in all galls with trichomes of their study, not sharing the hypothesis of Fernandes \& Price (1988) who attribute the presence of trichomes protection against parasitoids.

The galls of Eugenia punicifolia Kunth (DC.) Stryphnodendron obovatum Benth. and Arrabidaea sp. were found in the color green and also brown (Figure 9). Urso-Guimarães \& Scarelli-Santos (2003) found three morphotypes those had different colors and also indicated those this change was related to the maturation time of the galls. These data indicates that the use of color as a characteristic to identify galls should be used with caution because galls will change color according to the maturation stage and this should be analyzed in the characterizations of galls.

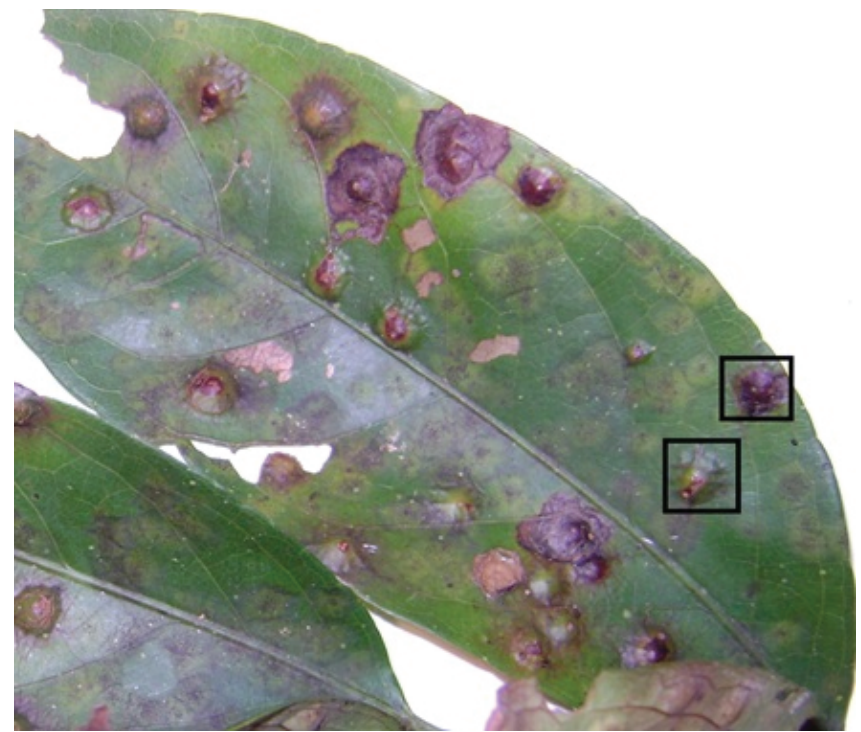

Figure 9. Example of galls of Eugenia punicifolia Kunth (DC.) in two stages of development with green and brown coloration of Ecological Station of Jataí (SP).

Another data was the new record of the species, Psychotria carthagenensis Jacq., P. tricophora Müll.Arg., P. suturella Müll.Arg. (Rubiaceae) and Serjania erecta Radlk. (Sapindaceae) in ES JATAÍ, as they are species of vines, not sampled by Toppa (2004) in his inventory of woody species. This record extends geographic distribution of these species.

The Diptera of the family Cecidomyiidae were responsible for the highest percentage of induction galls found (67.4\%), and for the galling habit (88\%). This result corroborate another data reported in other major studies in the literature, those indicates $58 \%$ of galls induced by Cecidomyiidae, according to Maia et al. (2008), 54\% Urso-Guimarães et al. (2006), and 93\%, according to Fernandes \& Negreiros (2006), demonstrating the importance of the family in community of gall makers.

The Hymenoptera parasitoids found are of the families Eurytomidae, Torymidae and Eulophidae, within the superfamily Chalcidoidea, which are known parasitoids wasp of Cecidomyiidae galls (Urso-Guimarães et al. 2003).

All Diptera identified are unpublished occurrences for ES JATAÍ, because as mentioned, there are no studies related to galling insects in that area. The occurrence of these species in ES JATAÍ increases their known geographical distribution.

More studies are needed to understand the heterogeneous distribution of fauna and flora within the various vegetation types of ES JATAÍ. Including studies that aim to explain the distribution of galls and gall makers of these environments, because as mentioned earlier, this fauna has great potential as bioindicator, but you need to know how it behaves under different vegetation types and changes in conservation status of areas.

\section{Acknowledgements}

To Luís Tauhyl and João Vitor and technician Almir Calazans for field assistance. To Prof. Dr. Ingrid Koch (Universidade Federal de São Carlos) for helping in botanical identifications, to the manager of the ES JATAÍ, Dr. Edson Montilha (Instituto Florestal, Secretaria do Meio Ambiente do Estado de São Paulo) for enabling research 
inside the conservation area and to $\mathrm{CNPq}$ for financial support (Victor Satoru Saito was supported by PIBIC/CNPq for this work).

\section{References}

BREGONCI, J.M., POLYCARPO, P.V. \& MAIA, V.C. 2010. Insect galls of the Parque Estadual Paulo César Vinha (Guarapari, ES, Brazil). Biota Neotrop. 10(1): http://www.biotaneotropica.org.br/v10n1/pt/abstract?in ventory+bn01410012010 (último acesso em 20/02/2011)

CARNEIRO, M.A.A., BRANCO, C.S.A., BRAGA, C.E.D., ALMADA, E.D., COSTA, M.B.M., MAIA, V.C. \& FERNANDES, G.W. 2009. Are gall midge species (Diptera, Cecidomyiidae) host-plant specialists? Rev. Bras. Entomol. 53(3):365-378. http://dx.doi.org/10.1590/S008556262009000300010

ESPÍRITO-SANTO, M. M. \& FERNANDES, G. W. 2007. How many species of gall-inducing insects are there on earth, and where are there? Ann. Entomol. Soc. Am. 100:95-99. http://dx.doi.org/10.1603/00138746(2007)100[95:HMSOGI]2.0.CO;2

FERNANDES, G.W. \& NEGREIROS, D. 2006. A comunidade de insetos galhadores da RPPN Fazenda Bulcão, Aimorés, Minas Gerais, Brasil. Lundiana 7:111-120.

FERNANDES, G.W., PRICE, P.W. 1988. Biogeographical gradients in galling species richness: tests of hypotheses. Oecologia 76:161-167.

FERNANDES, G.W., DE PAULA, A.S. \& LOYOLA JUNIOR, R. 1995. Distribuição diferencial de insetos galhadores entre habitats e seu possível uso como bioindicadores. Vida Silv. Neotrop. 4:133-139.

FUNDAÇÃO FLORESTAL, INSTITUTO FLORESTAL, UNIVERSIDADE FEDERAL DE SÃO CARLOS. In preparation. Plano de manejo da Estação Ecológica de Jataí.

GAGNÉ, R.J. 1994. The Gall Midges of the Neotropical Region. Cornell Univ. Press, Ithaca.

GAGNÉ, RJ. 1989. The Plant-Feeding gall midegs of North America. Comstock, Cornell University Press, Ithaca

GONÇALVES-ALVIM, S.J. \& FERNANDES, G.W. 2001. Biodiversity of galling insects: historical, community and habitat effects in four Neotropical savannas. Biod. Conserv. 10:79-98. http://dx.doi. org/10.1023/A:1016602213305

JULiÃO, G.R., FERNANDES, G.W., NEGREIROS, D., BEDÊ, L. \& ARAÚJO, R.C. 2005. Insetos galhadores associados a duas espécies de plantas invasoras de áreas urbanas e peri-urbanas. Rev. Bras. Entomol. 49:97-106. http://dx.doi.org/10.1590/S008556262005000100010

KRISTENSEN, N.P. 1991. The Insects of Australia. CSIRO. Cornell University Press, New York

LARA, A.C.F. \& FERNANDES, G.W. 1996. The highest diversity of galling insects: Serra do Cipó, Brazil. Biodivers. Lett. 3:111-114.

MAIA, V.C. 1995. Chaves para classificação de galhas de Cecidomyiidae (Diptera) em Myrtaceae na restinga da Barra de Maricá, Rio de Janeiro. Rev. Bras. Zool. 12:1009-1013. http://dx.doi.org/10.1590/S010181751995000400028

MAIA, V.C. 2001. The gall midges (Diptera, Cecidomyiidae) from three restingas of Rio de Janeiro State, Brazil. Rev. Bras. Zool. 18:583-629. http://dx.doi.org/10.1590/S0101-81752001000200028
MAIA, V.C. 2005. Catálogo dos Cecidomyiidae (Diptera) do estado do Rio de Janeiro. Biota Neotrop. 5(2): http://www.biotaneotropica.org.br/v5n2/ pt/abstract?inventory+BN00805022005 (último acesso em 22/05/2011).

MAIA, V.C. \& FERNANDES, G.W. 2004. Insect galls from Serra de São José (Tiradentes, MG, Brazil). Braz. J. Biol. 64:423-445. http://dx.doi. org/10.1590/S1519-69842004000300007

MAIA, V.C., MAGENTA, M.A.G. \& MARTINS, S.E. 2008. Ocorrência e caracterização de galhas de insetos em áreas de restinga de Bertioga (São Paulo, Brasil). Biota Neotrop. 8(1): http://www.biotaneotropica. org.br/v8n1/en/abstract?inventory+bn02408012008 (último acesso em 22/05/2011).

MANI, M.S. 1964. Ecology of Plant Gall. The Hague, Junk.

MÖHN, E. 1961.Gallmücken (Diptera, Itonididae) aus El Salvador. 4. Zur Phylogenie der Asphondyliidi der neotropischen und holarktischen region. Senck. Biol. 42:131-330.

PERUQUETTI, P.S.F. 2004. Odonata (libélulas) do município de Luís Antônio, São Paulo, Brasil: relação com o uso do solo e riqueza faunística. Tese de Doutorado, Universidade Federal de São Carlos, São Carlos.

PIRES, A.M.Z.C.R., SANTOS, J.E. \& PIRES, J.S.R. 2000. Caracterização ambiental de uma Unidade de Conservação. Estação Ecológica de Jataí, Luiz Antônio, SP. In Estudos integrados em ecossistemas. Estação Ecológica de Jataí. (J.E. Santos \& J.S.R. Pires, eds.). RiMa Editora, São Carlos, v.2, p.59-71.

PRICE, P.W., FERNANDES, G.W., LARA, A.C.F., BRAWN, J., GERLING, D., BAIRROS, H., WRIGHT, M.G., RIBEIRO, S.P. \& ROTHCLIFF, N. 1998. Global patterns in local number of insect galling species. J. Biogeogr. 25:581-591.

ROHFRITSCH, O. \& SHORTHOUSE, J.D. 1982. Insect galls. In Molecular biology of plant tumors. (G. Kahls \& J.S. Schell, eds.). Academic Press, New York, p.131-152.

SANTOS, J.C., ALMEIDA-CORTEZ, J.S. \& FERNANDES, G.W. 2011. Diversity of gall-inducing insects in the high altitude wetland forests in Pernambuco, Northeastern Brazil. Braz. J. Biol. 71:47-56. http://dx.doi. org/10.1590/S1519-69842011000100008

TOPPA, R.H. 2004. Estrutura e diversidade florística do componente arbóreoarbustivo nas diferentes fisionomias de Cerrado e suas correlações com as características edáficas na Estação Ecológica de Jataí, Luiz Antônio, SP. Tese de Doutorado, Universidade Federal de São Carlos, São Carlos.

TOPPA, R.H., DURIGAN, G., PIRES, J.S.R. \& DE FIORI, A. 2006. Mapeamento e caracterização das fitofisionomias da Estação Ecológica de Jataí. In Estudos Integrados em Ecossistemas. Estação Ecológica de Jataí (J.E. Santos, J.S.R. Pires \& L.E. Moschini, eds.). EdUFSCar, São Carlos, p.21-44.

URSO-GUIMARÃES, M.V., SCARELLI-SANTOS, C.\&BONIFÁCIO-SILVA A. C. 2003. Occurrrence and characterization of entomogen galls in plants from natural vegetation areas in Delfinópolis, MG, Brazil. Braz. J. Biol. 63:705-715. http://dx.doi.org/10.1590/S1519-69842003000400018

URSO-GUIMARÃES, M.V. \& SCARELLI-SANTOS, C. 2006. Galls and gall makers in plants from the Pe-Gigante Cerrado Reserve, Santa Rita do Passa Quatro, SP, Brazil. Braz. J. Biol. 66:357-369. http://dx.doi. org/10.1590/S1519-69842006000200018

WHITHAM, T.G. 1978. Territorial behavior of Pemphigus gall aphids. Nature 279:324-325. 